\title{
The Current Use of Web 2.0 Tools in University Teaching from the Perspective of Faculty Members at the College of Education
}

\author{
Abdelrahman M. Ahmed \\ Asst. Prof., Sultan Qaboos University, Muscat, Oman,abdoelhaj@squ.edu.om
}

Arwa Abdel Almuniem

Sudan University, Khartoum, Sudan,arwa8976@yahoo.com

\author{
Ahmed A. Almabhouh \\ Asst. Prof., Alaqsa University, Palestine,ahm_mb@yahoo.com
}

This study aimed to identify the current status of using Web 2.0 tools in university teaching by the faculty members of the College of Education at Sudan University of Science and Technology. The study used a descriptive analytical method based on the use of questionnaires and interviews. The questionnaire was administered to a sample of 40 members selected randomly from the study population. The results showed that the level of using Web 2.0 tools in university teaching by faculty was medium, and the highest level of usage was represented in the field of scientific research. The results also showed that there are no statistically significant differences on the use of Web 2.0 tools in university teaching due to the degree level, whereas the findings showed statistically significant differences on the use of Web 2.0 tools due to departmental specialisation. The results also showed that using Web 2.0 in teaching caused by some difficulties. In light of these results, a set of recommendations and further research are provided.

Keywords: internet applications, web 2.0, faculty members, Sudan University of Science and Technology, teaching and learning

\section{INTRODUCTION}

The educational process in the third millennium is facing many challenges due to rapid change in various cognitive, demographic, social, and economic fields as well as the field of technology and communications, and thus accelerating transmission of knowledge and science is the main feature. Therefore, all these factors pressurise educational institutions to keep pace with these developments and to develop new methods and techniques that contribute to the simplification of knowledge and ways to deliver this knowledge to students in successful and fast ways. Al Qadani (2007) confirms that computers and Internet applications have become important elements of people's daily lives, and that educational institutions do not confine their interest to the cultural deployment of modern technologies, but rather focus on teaching skills to use 
and integrate them into the educational process. Thus, with the development of computers and the means of communication, the Internet appeared and provided a great amount of information in all disciplines. The Internet has changed the way that educational material is presented to students and trainees, with websites, mailing lists, and discussion forums playing an important role in the delivery of educational material. However, with the emergence of new technologies for delivering the educational material, the previous media began to lose its luster and was gradually replaced by new Web 2.0 technologies. The term of Web 2.0 refers to the "next generation" of Internet technologies that facilitate interaction with the user (Velagapudi, 2013). It describes the leap from a primarily static World Wide Web where most websites were online brochures consumed by the end user, to today's web, where sites are dynamically generated and content is both created and shared by end users. In other words, Web 2.0 sites encourage collaboration, allowing social interaction to form virtual communities around user-generated content. Web 2.0 technologies have the potential to create more interactive and powerful learning environments in which learners become knowledge creators, producers, editors, and evaluators (Richardson, 2009). These technologies provide Internet-based systems that offer pedagogical applications for online teaching. Some examples of these tools are: blogs, discussion boards, audio/video chat, RSS feeds, file sharing, social media platforms, interactive whiteboards, and wikis. All of these tools are Web 2.0 platform, and each captures the essence of different pedagogical elements for teaching where have been documented in the literature, such as content sharing, assessing student performance, communicating and collaborating with students, and audio/video recording lecture sessions (Velagapudi, 2013).

\section{LITERATURE REVIEW}

Barnett at al. (2004) state that Internet applications such as e-mail, websites, and news groups have benefitted traditional classroom knowledge delivery and have positively impacted the course of delivery and design in many colleges and universities. In the past few years Web 2.0 has emerged, further enhancing the teaching and learning environment in higher education. Despite the gradual increase of these technologies there is no commonly accepted definition of Web 2.0 in the literature, and as such different definitions are used in different contexts. Some scholars focus on the technical side of Web 2.0, while other scholars emphasise the evolving culture of the internet due to Web 2.0 (Birdsall, 2007; Miller, 2005; O’Reilly, 2005; Sodt \& Summey, 2009). With the read/write access provided by Web 2.0 tools, users have become active online participants and content creators. They not only find information on the Internet, but they also create and share content (Thompson, 2007). Weller (2013) states that Web 2.0 tools such as YouTube, Skype, Facebook, Google Docs, Word Press, Blogger, Wikipedia, and Padlet have allowed users to easily create and publish content online and to connect with other people from all over the world who have similar interests. These technologies could be characterised by openness, user participation, knowledge sharing, social networking and collaboration, and user-created content (Alexander, 2006; Brown \& Adler, 2008; Richardson, 2009). Moreover, Web 2.0 tools can be used to develop new learning strategies that can enhance student motivation, improve participation, 
facilitate learning and social skills, and increase self-directed learning (Redecker at al., 2010).

The studies that have addressed the issue of Web 2.0 technologies in university teaching are relatively few, whether at the local or national level or internationally. One such recent study by Al Tayeb (2014) deals with the aspect at the local level, showing that the majority of faculty members in Sudanese universities $(75 \%)$ have a positive attitude towards using the Internet in scientific research. The results also showed that there were no significant differences in the level of using the Internet in scientific research due to the rank and years of experience variables, whilst the result showed significant differences due to the specialisation in favour of the professors of Applied Sciences.

In addition, Al Tahir (2013) conducted a study on the current use of Web 2.0 tools in teaching in the College of Education in Khartoum state, Sudan. Results showed that the most important obstacles were the lack of knowledge and skills to use Web 2.0 tools by the faculty members. The findings of this study also showed that there are a number of difficulties facing the use of Internet applications in university teaching such as the lack of adequate training for faculty members and students to use computers and the Internet. At the national level, Al Matrafi (2009) conducted a study to identify the current status of using the Internet by natural sciences faculty members in Saudi universities and the impact of rank, expertise, and specialisation in faculty members' responses. The results showed that there were significant differences between faculty members due to rank of axes $(1,2$, and 4$)$, no significant differences due to the rank for the rest of the axes, and no significant differences due to scientific experience. Many studies have been conducted at the international level, and Estable (2014) found that the intrinsic factors of a lack of time and training were the main barriers to use Web 2.0 tools. The respondents reported positive views of Web 2.0 use in class, with $75 \%$ saying that these tools would benefit students and $83 \%$ saying they would benefit teacher-student interactions. Tyagi (2012) conducted a study in six universities in the National Capital Region (NCR) of India to explore the usage analysis of Web 2.0 technologies in learning environments by faculty members. The results reveal that the adoption of Web 2.0 tools at NCR universities is associated with important challenges (potential risks, institutional fears), and an effective strategy to deal with implementation problems may therefore include learning from others' experience, as well as open access to content and reliance on open platforms for knowledge sharing and creation. The results also indicate that the faculty's attitude and their perceived behavioural control are strong predictors of their intention to use Web 2.0. Sawant (2012) presents a study on investigation of Library and Information Science teacher's familiarity with Web 2.0 concepts, tools, services, and applications related to LIS education. The results reveal that most of the teachers use Web 2.0 for video sharing via YouTube but nearly half of the teachers never used Wikis. The main problem in using Web 2.0 in teaching was the lack of training programmes organised by universities and other institutions for teachers to use/teach Web 2.0 tools. Yuen at al. (2011) found that teachers indicated positive perceptions of the pedagogical benefits and importance of Web 2.0 tools for teaching and learning, and expressed interest in gaining further skills and understanding in order to more effectively and seamlessly integrate Web 2.0 tools to support and supplement classroom 
instruction. An and Williams (2010) conducted a study to explore best practices in teaching with Web 2.0 technologies as well as the benefits and barriers associated with this usage. The study results indicate that the major benefits of using Web 2.0 technologies in teaching include (1) interaction, communication, and collaboration, (2) knowledge creation, and (3) ease of use and flexibility. The major barriers that university instructors encounter in teaching with Web 2.0 technologies include uneasiness with openness and technical problems. The issue of using Web 2.0 tools in university teaching may provide both opportunities and as well as barriers that are yet to be investigated. Therefore, this research attempts to provide a breakdown of the current use of Internet applications in university teaching in some national and international universities and understanding the importance of and barriers to using Web 2.0 technologies, especially in higher education. In addition, the results of this study could be useful for all stakeholders who are using the Internet in university teaching in local and regional educational institutions.

\section{RESEARCH QUESTIONS}

The primary research question is as follows: What is the current status of using Web 2.0 tools in university teaching by the faculty members of the College of Education at Sudan University of Science and Technology?

The sub-research questions are:

i. To what degree do these faculty members use Web 2.0 tools in their university teaching?

ii. What is the importance of using Web 2.0 tools in university teaching by these faculty members, according to their point of view?

iii. What are the difficulties faced by these faculty members when attempting to use Web 2.0 tools in their teaching, according to their point of view?

iv. Are there any significant differences in the degree of the use of Web 2.0 tools in teaching by these faculty members due to academic rank and specialty?

\section{PURPOSE OF THE STUDY}

The purpose of this study is to investigate the current status of using Web 2.0 tools in university teaching by the faculty members of the College of Education at Sudan University of Science and Technology.

\section{OBJECTIVES}

The objectives of the present study were as follow:

i. to determine to what degree faculty members use Web 2.0 tools in their university teaching;

ii. to explore the importance of using Web 2.0 tools in university teaching by faculty members;

iii. to find out what are the difficulties faced by faculty members when attempting to use Web 2.0 tools in their teaching; and

iv. to determine if there any significant differences in the degree of the use of Web 2.0 tools in teaching by faculty members due to academic rank and specialty. 


\section{METHODS}

The researchers used a descriptive analytical method by using a survey approach to investigate the current status of using Web 2.0 tools in university teaching. The survey contained several qualitative questions centred on the use of and barriers to use of Web 2.0.

\section{POPULATION AND SAMPLE}

The target population of this study consisted of all faculty members of the College of Education at Sudan University of Science and Technology. The total number of the population was 71 individuals and all of them use Internet in teaching. A sample of 40 faculty members who routinely use at least one Web 2.0 tool in teaching was selected through stratified random sampling. The researchers divided the entire population into different subgroups according to their academic rank, the number of Web 2.0 used, and specialty or department. The total number of the participants in sample represented $56.3 \%$ of the total population.

\section{INSTRUMENT}

In order to develop the instruments, the researchers surveyed the literature and informally interviewed some faculty members to obtain initial information regarding their use of Web 2.0 tools in teaching. A questionnaire consisting of two sections was designed using the Google forms tool. The first section collects demographic data, whilst the second section consists of 44 Likert-type items, 16 for the level of use of Web 2.0 tools in teaching, 17 for their importance, and 11 to assess the perception of difficulties inhibiting Web 2.0 tools used in teaching. The survey was expected to take 10 to 15 minutes to be completed, and the instrument was given to a panel of faculty members for face validation. They reviewed the instrument and gave some suggestions, which the researchers used to revise the instrument accordingly. The reliability of the instrument was measured by Cronbach's alpha and was found to be 0.86 , which is sufficient for the purpose of this study. The questionnaire was administered online and data were collected in 2014. The researchers also used interviews by directing questions to a number of specialists in the field of educational technology from the College of Education at Sudan University of Science and Technology to find out the reality of the use of Web 2.0 tools in teaching.

\section{STATISTICAL ANALYSES}

The data were analysed using Statistical Package for the Social Sciences (SPSS-version 21). Initial data analysis used frequencies to provide a profile of respondents by demographic characteristics. The Kruskal Wallis test was used to differentiate between estimated average of the sample on the level of usage of Web 2.0 tools in teaching for academic rank and specialisation. Statistically significant differences were reported using p. $<0.05$. 


\section{FINDINGS AND DISCUSSION}

\section{Demographics of participants}

Table 1 summarises the demographics of the participants' data in terms of academic rank, number of years of teaching experience, and their specialty/departments. It is observed that out of 40, two were associate professors and above, 15 were assistant professors, and 23 were lecturers. More than half of the respondents had over 12 years of teaching experience $(57.5 \%$ ), whilst $22.5 \%$ had $5-12$ years of experience, and $20 \%$ had less than five years of experience.

Table 1: Frequency distributions of the respondents' demographic profile

\begin{tabular}{lrr}
\hline & Number of Participants $(n=40)$ & Percentage $\%$ \\
\hline Academic rank: & 2 & \\
Associate professor and above & 15 & 5 \\
Assistant professor & 23 & 37.5 \\
Lecturer & & 57.5 \\
Teaching experience: & 8 & \\
Less than 5 years & 9 & 20 \\
5 12 years & 23 & 22.5 \\
More than 12 years & & 57.5 \\
Specialty/Department: & 10 & \\
1. Educational Technology & 7 & $25 \%$ \\
2. Science & 5 & $17.5 \%$ \\
3. Languages & 2 & $12.5 \%$ \\
4. Art Education & 4 & $5 \%$ \\
5. Technical Education & 4 & $10 \%$ \\
6. Psychology & 2 & $10 \%$ \\
7. Basic Education & 6 & $5 \%$ \\
8. Educational Science & $15 \%$ \\
\hline
\end{tabular}

The faculty members were asked an open-ended question in order to ascertain which Web 2.0 tools they used in their teaching and learning processes. Only $11(27.5 \%)$ faculty members listed one or more of the following four tools:

i. Social media: Three teachers mentioned that they used Facebook to create groups that enable their students to communicate and share their comments on courserelated topics. Two additional faculty members reported that they used WhatsApp and Skype in order to provide virtual office hours and to communicate with students, especially postgraduates.

ii. YouTube: Six faculty members mentioned that they use YouTube videos relevant to course topics.

iii. Blogs: One faculty member used student blogs in class to help increase student participation and provide a collaborative reflection space for discussion of course topics.

iv. Online quizzes and grading tools: Four teachers reported that they use a number of online websites and tools to create quizzes for their courses. They mentioned that they used Google forms, quiz creator online, and the WizIQ website. 
The faculty members were also asked in the survey instrument to indicate the degree level of use with 16 five-point scale statements regarding the use of Web 2.0 tools in teaching and learning. Table 2 displays mean scores, standard deviation, ranks, and the degree of use for the whole axis, as well as for each item. The mean scores for individual statements ranged from 1.87 to 4.41 , with an overall mean response of 3.18 , which indicated that the degree of use for Web 2.0 tools in teaching and learning was medium according to the faculty members' points of view.

Table 2: Mean scores, standard deviation, ranks, and the degree of use of Web 2.0 tools in teaching and learning by the faculty members

\begin{tabular}{|c|c|c|c|c|c|}
\hline \multirow{2}{*}{\multicolumn{2}{|c|}{ Statement }} & \multicolumn{2}{|c|}{ Mean \& sd } & \multirow{3}{*}{$\begin{array}{l}\text { Rank } \\
16 \\
\end{array}$} & \multirow{3}{*}{$\begin{array}{l}\begin{array}{l}\text { Degree } \\
\text { of use }\end{array} \\
\text { Low } \\
\end{array}$} \\
\hline & & & \multirow{2}{*}{$\begin{array}{ll}s d \\
0.97\end{array}$} & & \\
\hline $1-$ & I deal with students through virtual classrooms. & & & & \\
\hline $2-$ & $\begin{array}{l}\text { I interact with my students through blogs in the } \\
\text { teaching process. }\end{array}$ & 2.52 & 1.31 & 13 & Low \\
\hline & $\begin{array}{l}\text { I communicate with students using instant } \\
\text { messenger }\end{array}$ & 4.26 & 1.09 & 4 & High \\
\hline 4- & I communicate with students through Twitter. & 1.91 & 1.04 & 15 & Low \\
\hline $5-$ & I communicate with students through Facebook. & 2.26 & 1.14 & 14 & Low \\
\hline 6- & $\begin{array}{l}\text { I communicate with my colleagues through my } \\
\text { personal website. }\end{array}$ & 3.57 & 1.31 & 6 & Medium \\
\hline 7- & I analyse the student grades online. & 2.83 & 1.47 & 9 & Low \\
\hline $8-$ & I create quizzes to assess student performance. & 2.61 & 1.23 & 12 & Low \\
\hline 9- & I use websites to present course materials. & 2.87 & 1.42 & 8 & Low \\
\hline $\begin{array}{l}10 \\
-\end{array}$ & I use Web 2.0 tools in scientific research & 4.41 & 0.79 & 1 & High \\
\hline $\begin{array}{ll}11 \\
-\end{array}$ & I search for information. & 4.17 & 1.15 & 5 & High \\
\hline 12 & I ascertain what is new in my field. & 4.39 & 0.78 & 3 & High \\
\hline $\begin{array}{l}13 \\
-\end{array}$ & I use Web 2.0's bookmarking application. & 2.78 & 1.41 & 10 & Low \\
\hline $\begin{array}{l}14 \\
-\end{array}$ & I create lectures and tasks for students. & 3.30 & 1.39 & 7 & Medium \\
\hline & $\begin{array}{l}\text { I download books, articles, and research } \\
\text { materials }\end{array}$ & 4.43 & 0.79 & 2 & High \\
\hline $\begin{array}{l}16 \\
-\end{array}$ & I share YouTube videos with students. & 2.70 & 1.19 & 11 & Low \\
\hline & General degree of use & 3.18 & 1.15 & & Medium \\
\hline
\end{tabular}

The top three usages of Web 2.0 tools are as follows: (a) the use of such tools in scientific research represented the highest degree of use (4.41), followed by (b) downloading books, articles, and research materials (4.43); and (c) ascertaining what is new in the field (4.41). These results may be explained by the fact that the teachers are personally motivated to use the internet in their research field to access the latest research studies and ascertain what is new in the field. The interviews with educational technology specialists and others who are interested in using Internet applications indicated that their actual use of Web 2.0 tools is limited to searching for information 
from websites such as academia.edu and researchgate.net, as well as blogs, social networking sites, and podcasting using YouTube. This result supports the findings of prior research (Al Tayeb, 2014; Tyagi, 2012), thus confirming that faculty members use Internet applications in scientific research. Moreover, the study showed nine items that represent a somewhat lower level of Web 2.0 tool usage in teaching by faculty members. The average mean score for these items ranged between 1.87 and $2.87(1,4,5,2,8,16$, 13,7 , and 9), respectively. This result could be explained due to the lack of necessary training for the use of Web 2.0 technologies and also due to the low internet connectivity, which inhibits these tools from being integrated in teaching. These results are similar to those reported by Al Tahir (2013) and Sawant (2012), but in contrast with those reported by Yuen et al. (2011). The results also indicate that there is a disparity between faculty members in terms of the use of Web 2.0 tools in teaching and learning due to various issues such as attitudes, educational environments, and educational cultures.

The faculty members were asked to rate the importance of using Web 2.0 tools in university teaching according to their point of view on a five-point scale, ranging from 1 (very low) to 5 (very high). Table 3 shows the mean scores, standard deviation, ranks, and the degree of the importance of using Web 2.0 in teaching for the whole axis, as well as for each item. The mean scores for individual statements ranged from 4.09 to 4.65 , with an overall mean response of 4.37 , which indicated that the degree of importance for using Web 2.0 tools in university teaching was generally high.

Table 3: Mean scores, standard deviation, ranks, and the degree of importance for using Web 2.0 tools in teaching and learning according to the faculty members

\begin{tabular}{llllll}
\hline \multicolumn{2}{l}{ Statement } & \multicolumn{2}{l}{ Mean \& sd } & Rank & $\begin{array}{l}\text { Degree } \\
\text { of use }\end{array}$ \\
\cline { 3 - 4 } $1-$ & To provide collaborative learning opportunities. & 4.57 & 0.66 & 2 & High \\
\hline $2-$ & $\begin{array}{l}\text { To help students become more proficient in } \\
\text { writing and technology skills. }\end{array}$ & 4.39 & 0.72 & 8 & High \\
\hline $3-$ & $\begin{array}{l}\text { To find and share educational resources with } \\
\text { students. }\end{array}$ & 4.65 & 0.65 & 1 & High \\
\hline 4- & To promote self-publishing on the web. & 4.44 & 0.73 & 7 & High \\
\hline $5-$ & $\begin{array}{l}\text { To facilitate communication and feedback } \\
\text { between learners and teachers. }\end{array}$ & 4.51 & 0.67 & 4 & High \\
\hline $6-$ & To provide a flexible learning environment. & 4.09 & 0.99 & 16 & High \\
\hline $7-$ & $\begin{array}{l}\text { To encourage students to interact and build a } \\
\text { learning community. }\end{array}$ & 4.52 & 0.68 & 5 & High \\
\hline $8-$ & $\begin{array}{l}\text { To help learners to create and publish their own } \\
\text { material. }\end{array}$ & 4.35 & 0.94 & 9 & High \\
\hline $9-$ & To support innovative teaching methods. & 4.44 & 0.90 & 6 & High \\
\hline $10-$ & To create quizzes and tasks for students. & 4.17 & 0.83 & 15 & High \\
\hline $11-$ & To support web-based teaching and research. & 4.35 & 0.83 & 10 & High \\
\hline $12-$ & To promote knowledge sharing. & 4.57 & 0.73 & 3 & High \\
\hline $13-$ & To help teachers to design classroom activities. & 4.35 & 0.83 & 11 & High \\
\hline $14-$ & $\begin{array}{l}\text { To bookmark web pages and share them with } \\
\text { students. }\end{array}$ & 4.30 & 0.77 & 12 & High \\
\hline
\end{tabular}




\begin{tabular}{llllll}
\hline $15-$ & To share YouTube videos with students. & 4.22 & 0.90 & 14 & High \\
\hline $16-$ & $\begin{array}{l}\text { To help students to download the teaching } \\
\text { materials. }\end{array}$ & 4.09 & 0.85 & 17 & High \\
\hline $17-$ & To keep up-to-date on related topic of interest. & 4.22 & 0.85 & 13 & High \\
\hline General importance of use & 4.37 & 0.80 & & High \\
\hline
\end{tabular}

The top six statements for the importance of using Web 2.0 tools in teaching as viewed by the faculty members are as follows: (a) to find and share educational resources with students (mean score 4.65); (b) to provide collaborative learning opportunities (4.57); (c) to promote knowledge sharing (4.57); (d) to facilitate communication and feedback between learners and teachers (4.52); (e) to encourage students to interact and build a learning community (4.52); and, (f) to support innovative teaching methods (4.44). These results could be explained by that Web 2.0 tools have many advantages in learning which allow for providing a more flexible learning environment, help build a sense of community, increase interaction and communication among the instructor, students, and other people, and promote collaboration and resource sharing. The full results of the importance of using Web 2.0 in teaching can be viewed in Table 3 . The researchers could explain this result due to faculty member realisation of the role that Internet applications play in the educational process, which has become an important part of our daily lives. Furthermore, educational institutions do not confine their interest in the cultural deployment of modern technologies, but focus on teaching skills to use and integrate them into the educational process (Al Qadani, 2007). Moreover, the use of Web 2.0 technologies in educational environments has become an important issue for developing educational content and teaching tools that enrich the educational environment with the necessary methods and techniques. This will help prepare educated generations that have the ability to communicate and deal positively with the modern issues and technologies under proliferation and openness. Therefore, the use of Web 2.0 technologies is of major importance to the faculty members in both their teaching and scientific research. These results are similar to those reported by Estable (2014), who aimed to analyse the current uses of emerging Web 2.0 technologies in higher education with the intent to understand better which tools teachers are using in the classroom. Her results showed that the respondents reported positive views of Web 2.0 use in class, with $75 \%$ saying that these tools would benefit students and $83 \%$ saying they would benefit teacher-student interactions.

Table 4: Mean scores, standard deviation, ranks, and the degree of difficulties for using Web 2.0 tools in teaching and learning by faculty members

\begin{tabular}{|c|c|c|c|c|c|}
\hline \multirow{2}{*}{\multicolumn{2}{|c|}{ Statement }} & \multicolumn{2}{|c|}{ Mean \& sd } & \multirow[t]{2}{*}{ Rank } & \multirow{2}{*}{$\begin{array}{l}\text { Degree } \\
\text { of use }\end{array}$} \\
\hline & & $\mathrm{M}$ & $\mathrm{Sd}$ & & \\
\hline $1-$ & $\begin{array}{l}\text { Lack of training courses on how to use Web } 2.0 \text { in } \\
\text { teaching and learning. }\end{array}$ & 4.44 & 0.89 & 1 & High \\
\hline $2-$ & $\begin{array}{l}\text { No interest in using Web } 2.0 \text { in teaching and } \\
\text { learning. }\end{array}$ & 1.83 & 1.07 & 11 & Low \\
\hline $3-$ & $\begin{array}{l}\text { Absence of a future plan to develop and use Web } \\
2.0 \text { technologies in teaching processes. }\end{array}$ & 3.57 & 1.53 & 4 & Medium \\
\hline 4 & Lack of administrative support. & 3.52 & 1.27 & 5 & Medium \\
\hline & Student reticence to participate in Web 2.0 & 4.35 & 0.94 & 2 & High \\
\hline
\end{tabular}




\begin{tabular}{llllll}
\hline & technologies. & & & & \\
\hline $6-$ & $\begin{array}{l}\text { Low speed of internet for downloading web pages } \\
\text { and files. }\end{array}$ & 3.13 & 1.42 & 8 & Medium \\
\hline $7-$ & Increased administrative work and teaching load. & 4.09 & 0.85 & 3 & High \\
\hline $8-$ & $\begin{array}{l}\text { Out-dated computers to use Web 2.0 technologies in } \\
\text { teaching. }\end{array}$ & 2.26 & 1.36 & 10 & Low \\
\hline $9-$ & High cost of using Internet applications. & 3.26 & 1.32 & 6 & Medium \\
\hline 10 & High cost of devices and applications. & 3.26 & 1.32 & 7 & Medium \\
\hline- & Lack of time to learn how to use Web 2.0 tools. & 2.87 & 1.55 & 9 & Low \\
\hline & General level of difficulties of use & 3.32 & 1.24 & & Medium \\
\hline
\end{tabular}

Study participants were asked to highlight potential difficulties of using Web 2.0 tools in teaching and learning processes. The top four reported difficulties were as follows: (a) a lack of training courses on how to use them, (mean score: 4.44); (b) student reticence to participate because of their uneasiness with the openness of using such web tools (4.35); (c) the increasing administrative work and teaching load (4.09); and, (d) the absence of a future plan to develop and use Web 2.0 technologies in teaching processes (3.57). These results could be explained that the open nature of Web 2.0 technologies (An \& Williams, 2010) is wonderful, but sometimes anyone can see your work. If non class members have access to the wiki or virtual world, they can disrupt the class or cause damage (sabotage) to the environment. The full results are documented in Table 4. These results may be explained by the fact that most universities in Sudan have poor facilities and environments. In addition to the above results, the faculty members were asked an open-ended question in order to ascertain the difficulties they face when using Web 2.0 tools in their teaching and learning processes. They reported that Web 2.0 tools are still new to many teachers and students, and some students are very uncomfortable with the openness and are thus unwilling to participate and use Web 2.0 technologies. This study supports previous findings (An \& Williams, 2010; Sawant, 2012; Tyagi, 2012; Al Tayeb, 2014; Al Tahir, 2014), confirming that the most common barriers to Web 2.0 use in teaching and learning are as follows: time constraints, poor facilities and tools, lack of training and support, student reticence, and technical problems. All of these issues hinder the effort of teachers to integrate new technologies in their teaching and learning processes.

The Kruskal Wallis test was used to differentiate between estimated average of the sample on the level of usage of Web 2.0 tools in teaching for academic rank and specialisation.

Table 5: Kruskal Wallis test for mean difference in usage of Web 2.0 tools with respect to academic rank

\begin{tabular}{lllllll}
\hline & Academic rank & $n$ & Mean & $d f$ & $F$ & $P$ \\
\hline \multirow{3}{*}{ Usage } & Associate professor and above & 2 & 3.50 & & & \\
\cline { 2 - 5 } 2 & Assistant professor & 15 & 3.59 & & \multirow{2}{*}{1.41} & 0.50 \\
\cline { 2 - 5 } & Lecturer & 23 & 4.15 & & & \\
\hline
\end{tabular}


It is clear from Table 5 that there were no significant differences among the three groups of academic ranks (associate professor and above, assistant professor, and lecturer) on Web 2.0 use in teaching $(\mathrm{F} 2=1.41, \mathrm{p}>0.05$ ). This result could be explained by taking into consideration the point that the instructional uses of Web 2.0 technologies are changed and transform access to information, and could be used by all academic ranks especially for knowledge transfer and communication. This result is supported by studies that show no significant differences regarding the use of technology, such as that of Al Tayeb (2014), who found no significant relationship between the use of the Internet applications and academic rank.

Table 6: Kruskal Wallis test for mean difference in usage of Web 2.0 tools with respect to specialisation

\begin{tabular}{|c|c|c|c|c|c|c|}
\hline & Specialisation & $n$ & Mean & $d f$ & $F$ & $p$ \\
\hline \multirow{8}{*}{ Usage } & Science Education & 7 & 4.29 & \multirow{8}{*}{7} & \multirow{8}{*}{25.21} & \multirow{8}{*}{0.001} \\
\hline & Technical Education & 4 & 3.75 & & & \\
\hline & Art Education & 2 & 3.75 & & & \\
\hline & Language Education & 5 & 3.60 & & & \\
\hline & Educational Psychology & 4 & 3.00 & & & \\
\hline & Educational Science & 6 & 3.75 & & & \\
\hline & Educational Technology & 10 & 4.78 & & & \\
\hline & Basic Education & 2 & 4.00 & & & \\
\hline
\end{tabular}

It is clear from Table 6 that there were significant differences among the eight groups of specialisations (Science Education, Technical Education, Art Education, Language Education, Educational Psychology, Educational Science, Educational Technology, and Basic Education) on Web 2.0 use in teaching $(\mathrm{F} 7=25.21, \mathrm{p}<0.05)$. The faculty members in the departments of Educational Technology and Science Education reported a significantly higher mean value (4.78 and 4.29, respectively) of Web 2.0 usage than their counterparts in other departments $($ Mean $\leq 4)$. This result could be justified by the fact that the majority of the faculty members in the Department of Educational Technology have a Master's or $\mathrm{PhD}$ degree in Computer Integrated Education programme from Sudan University of Science and Technology in association with the University of Pretoria in South Africa. This is a unique specialisation in the College of Education, and the programme is concerned with how teachers integrate computers and the Internet in their teaching and learning. Thus, their level of use for Internet applications and Web 2.0 tools were advanced and extensive. The interview with some faculty members also yielded the fact that the majority of the faculty members in the Science Department were using the Internet to access information and to ascertain what is new in their field (e.g., chemistry, physics, or mathematics). This might also increase their level of use for Web 2.0 tools in teaching and learning. The results of this study match those of Al Tayeb (2014), who indicated that there were significant differences in the level of use for internet applications due to a specialisation variable in favour of science teachers. 


\section{FINDINGS}

The findings of this study showed that the degree of using Web (2.0) tools in teaching and learning as rated by faculty members was between the ranges of "low" and "very high", with an overall mean response of (3.18), that is indicated the moderate level of usage of Web 2.0 in teaching. The faculty members used some of Web 2.0 tools in their teaching and learning process as follow:

i. Social media: (Facebook, WhatsApp and Skype for virtual office hours and to communicate with students, especially the postgraduate students ).

ii. YouTube: searching for YouTube videos which are relevant to their course topics.

iii. Blogs: using student blogs in class to help increase student participation on the topics.

iv. Online quiz and grading tools: using a number of online website and tools to create their quizzes for their courses. (Google forms, quiz creator online, and WizIQ platform).

The finding also found that the faculty members used Web (2.0) tools to search for information and connected with other researchers around the world (e. g., academia.edu, researchgate.net).

In addition, the results showed that the degree of importance for using Web (2.0) tools in university teaching was high according to the faculty members' point of view (4.4).

The faculty members rated the first four items as of high barriers as follow:

i. lack of training courses on how to use web 2.0 tools in teaching $($ mean $=4.4)$;

ii. the weakness of students admission to participate because of their uncomfortable with openness of using such web (mean $=4.4$ );

iii. The increasing of administrative work and teaching load (mean $=4.1)$; and

iv. absence of the future plan to develop and use of web 2.0 technologies in teaching process $($ mean $=3.6)$.

\section{CONCLUSIONS}

The goal of this research was to investigate the current status of using Web 2.0 tools in university teaching by the faculty members of the College of Education at Sudan University of Science and Technology. A survey was conducted and the responses of 40 participants were analysed. Results suggest that the degree of Web 2.0 tool usage in teaching and learning across all academic ranks was medium according to the faculty members' point of view. It was thought that the rapid advance of technology and increasing student use were encouraging the faculty to use technology in their classroom, but those individuals who participated in this study were self-motivated to use Web 2.0 for teaching purposes. First, the study found that the top three usages of Web 2.0 tools by educators are as follow: (a) for scientific research, (b) to download books, articles, and research materials, and (c) to discover what is new in the field. Second, it showed that the degree of importance for using Web 2.0 tools in university teaching by faculty members was high. The study found that the faculty members viewed the importance of using Web 2.0 tools in teaching as follows: (a) to help find 
and share educational resources, (b) to provide collaborative learning opportunities, (c) to promote knowledge sharing, (d) to facilitate communication and feedback between learners and teachers, (e) to encourage students to interact and build a learning community, and (f) to support innovative teaching methods. Third, the study found that there were some difficulties encountered by the faculty members when attempting to use Web 2.0 tools in teaching and learning. The top four reported difficulties were as follows: (a) lack of training courses on how to use them, (b) student reticence because of their uneasiness with the openness of using such web tools, (c) the increase of administrative work and teaching load, and (d) the absence of future plans to develop and use Web 2.0 technologies in the teaching process. Finally, the results found that there are no significant differences among the three groups of academic ranks (associate professor and above, assistant professor, and lecturer) on the usage of Web 2.0 in teaching and learning. However, the results showed that there was a significant difference among the eight groups of specialisations on Web 2.0 usage in favour of the faculty members in the departments of Educational Technology and Science Education.

\section{RECOMMADATIONS}

According to these study findings, the researchers recommend the following:

i. Educational institutes should follow the continuous development of Web 2.0 technologies and encourage teachers to benefit from their free services in teaching and learning processes.

ii. Training sessions and workshops should be designed and developed to provide faculty members with a basic knowledge of Web 2.0 technologies and how they can be used in teaching and learning.

iii. The administrators in the Colleges of Education in Arab universities must develop a plan to benefit from the best practices of the use of technology innovations which are applied in the most prestigious universities in developed countries.

\section{REFERENCES}

Al Ghadian, A. (2007). The use of Computer and Internet by students of the Islamic University of Imam Muhammad bin Saud. Qatar University, Journal of Educational Sciences, (13).

Al Tahir, A. (2013). The current status of using Web 2.0 tools on the Internet in teaching in the Colleges of Education in Khartoum. Unpublished master dissertation, Sudan University of Science and Technology.

Al Tayeb, W. (2014). The use of the Internet by Sudanese Universities' faculty members and their attitude in scientific research. Unpublished doctoral dissertation, Sudan University of Science and Technology.

Alexander, B. (2006). Web 2.0: A new wave of innovation for teaching and learning? EDUCAUSE Review, 41(2), 32-44. 
An, J. \& Williams, K. (2010). Teaching with Web 2.0 technologies: Benefits, barriers, and lessons learned. International Journal of Instructional Technology and Distance Learning, 7(3), 41-48.

Barnett, M., Keating, T., Harwook, W., \& Saam, J. (2004). Using emerging technologies to help bridge the gap between university theory and classroom practice: Challenges and successes. School Sciences \& Mathematics, 102(6), 299-314.

Bell, A. (2009). Exploring Web 2.0: Second generation interactive tools - blogs, podcast, wikis, networking, virtual worlds, and more. Georgetown, TX: Katy Crossing Press.

Birdsall, F. (2007). Web 2.0 as a Social Movement. Webology, 4(2), Article 40. Retrieved February 7, 2015 from http://www.webology.org/2007/v4n2/a40.html

Estable, S. (2014). Web 2.0 use in higher education. European Journal of Open, Distance, and eLearning,(2) . Retrieved August 13, 2014 from http://www.eurodl.org/?p=current\&article=655.

Miller, P. (2005). Web 2.0: Building the New Library. Ariadne. Retrieved March 19, 2015 from http://www.ariadne.ac.uk/issue45/miller/

O'Reilly, T. (2005). What is Web 2.0. Retrieved February 7, 2015 from http://oreilly.com/web2/archive/whatis- web-20.html

Redecker at al., (2010). Learning 2.0 - The use of social computing to enhance lifelong learning, European Commission, Joint Research Centre, Institute for Prospective Technological Studies (IPTS), Seville, Spain.

Richardson, W. (2009). Blogs, wikis, podcasts, and other powerful web tools for classrooms $\left(2^{\text {nd }}\right.$ ed). Thousand Oaks, CA: Corwin Press.

Sawant, S. (2012). The study of the use of web 2.0 tools in LIS education in India. Library Hi Tech News, 29(2), 11-15.

Sodt, M., \& Summey, P. (2009). Beyond the Library's Walls: Using Library 2.0 Tools to Reach Out to All Users. Journal of Library Administration, 49, pp.97-109.

Thompson, J. (2007). Is education 1.0 ready for web 2.0 students? Innovate, 3, 4.

Tyagi, S. (2012). Adoption of Web 2.0 technology in higher education: A case study of universities in National Capital Region, India. International Journal of Education and Development using Information and Communication Technology (IJEDICT) 8, 28-43.

Velagapudi, M. (2013). 18 FREE Web 2.0 Tools for Teachers, WizIQ, Inc.

Weller, A. (2013). The use of Web 2.0 technology for pre-service teacher learning in science education, Journal of Research in Teacher Education, 2, 40-46.

Yuen, S. at al., (2011). Perceptions, interest, and use: Teachers and web 2.0 tools in education. International Journal of Technology in Teaching and Learning, 2, 109-123 
Zinbarg, R. at al..(2006). Estimating generalizability to a latent variable common to all of a scale's indicators: A comparison of estimators for $\omega \mathrm{h}$. Applied Psychological Measurement, 2, 121-144.

\section{Turkish Abstract}

Sudan Bilim ve Teknoloji Üniversitesi Eğitim Fakültesi Öğretim Üyelerinin Gözünden Öğretimde Web 2.0 Araçlarının Kullanımı

Bu çalışma Sudan Bilim ve Teknoloji Üniversitesi Eğitim Fakültesi öğretim üyelerinin Web 2.0 araçlarını üniversite öğretiminde kullanma durumlarını ortaya çıkarmayı amaçlamaktadır. Çalışma anketler ve görüşmelerin kullanımı temelli betimleyici analiz metodları kullanmıştır. Anket evrenden rassal olarak seçilen 40 kişilik örneklem üzerinde uygulanmıştır. Sonuçlar öğretim üyeleri tarafından Web 2.0 kullanım düzeylerinin orta olduğunu ve en yüksek kullanımın bilimsel araştırma alanınnda olduğunu göstermiştir. Sonuçlar ayrıca seviyeye göre Web 2.0 kullanımının anlamlı olarak farklılaşmadığını fakat dölüm uzmlığına göre anlamlı olarak farklılaştığını göstermiştir. Ayrıca öğretimde Web 2.0 kullanımı bazı zorluklara neden olmuştur. Bu sonuçların 1şığında bir takım öneriler ve gelecek araştırma önerileri sunulmuştur.

Anahtar Kelimeler: internet uygulamaları, Web 2.0, öğretim üyeleri, Sudan Bilim ve Teknoloji Üniversitesi, öğretim ve öğrenme

\section{French Abstract}

L'Utilisation Actuelle de Web 2.0 Outils dans Université Enseignant de la Perspective de Membres de Faculté au Collège d'Enseignement dans Université du Soudan de Science et Technologie

Cette étude a eu pour but d'identifier le statut actuel d'utiliser le Web 2.0 outils dans l'université enseignant par les membres de faculté du Collège d'Éducation à l'Université du Soudan de Science et la Technologie. L'étude a utilisé une méthode analytique descriptive basée sur l'utilisation de questionnaires et des entretiens(interviews). Le questionnaire a été administré à un échantillon de 40 membres choisis aléatoirement de la population d'étude. Les résultats ont montré que le niveau d'utiliser le Web 2.0 outils dans l'université enseignant par la faculté étaient moyens et le niveau le plus haut d'utilisation a été représenté dans le domaine de la recherche scientifique. Les résultats ont aussi montré qu'il n'y a pas statistiquement de différences significatives sur l'utilisation de Web 2.0 outils dans l'université enseignant en raison du niveau de degré, tandis que les découvertes ont montré des différences statistiquement significatives sur l'utilisation de Web 2.0 outils en raison de la spécialisation départementale. Les résultats ont aussi montré que l'utilisation du Web 2.0 dans l'enseignement de causés par quelques difficultés. À la lumière de ces résultats, on fournit un ensemble de recommandations et des recherches plus approfondies.

Mots Clés: applications Internet, Web 2.0, membres de faculté, Université du Soudan de Science et Technologie, enseignement et apprentissage 


\section{Arabic Abstract}

استخدام الحالي من 2.0 أدوات ويب في التدريس الجامعي من وجهة نظر أعضاء هيئة التدريس في كلية التربية في جامعة السودان للعلوم والتكنولوجن النوبيا

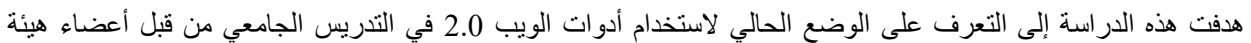

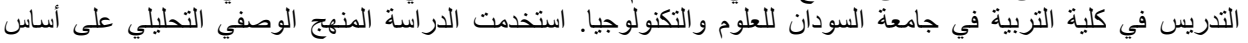

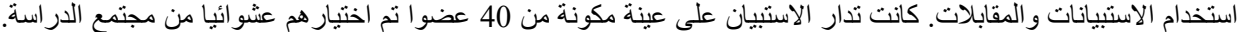

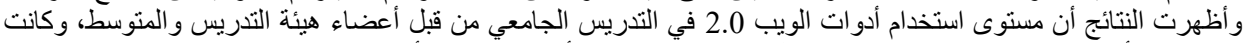

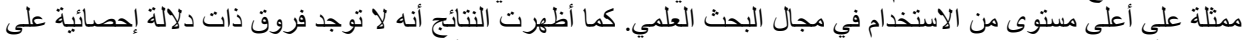

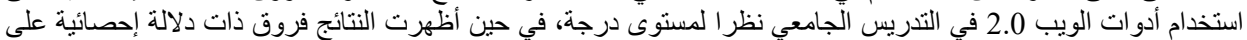

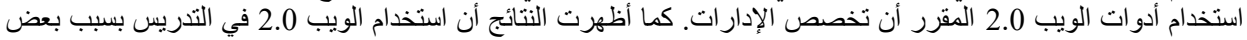

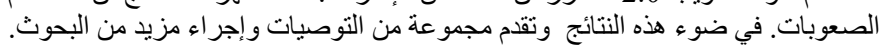

كلمات البحث: تطبيقات الإنترنت، الويب 2.0، أعضاء هيئة التدريس، جامعة السودان للعلوم و التكنولوجيا، التعليج و التعلم 